\title{
TOXIC EFFECT OF ORE MINING ON SOIL AND WATER QUALITY AT
}

\section{CHHATTISGARH, INDIA}

\section{S.K. Lokhande ${ }^{*}$, A. P. Vanerkar ${ }^{b}$, A. B. Fulkec, M. D. Giripunje ${ }^{d}$,} P. U. Meshramd

a Analytical Instrumentation Division, National Environmental Engineering Research Institute (CSIR-NEERI), Nagpur, India

b National Institute of Miners' Health (NIMH), Nagpur, India

c Environmental Health Division, National Environmental Engineering Research Institute (CSIR-NEERI), Nagpur, India.

d Department of Environmental Science, Sevadal Mahila Mahavidyalaya, Nagpur- 440015, Maharashtra, India.

*Corresponding author.

$$
\text { Tel.: +91-712-2249892, Fax: +91-0712- } 2249875
$$

Email: s_lokhande@neeri.res.in

\begin{abstract}
Mining involves various activities for extraction of minerals and metals from the earth. The heavy metal content of these samples obtained from mine site to study the distribution pattern of trace metals due to mining activity. Results indicated that the soil samples collected showed very high content of heavy metals, especially, iron being determined in the range of 2092- $3106 \mathrm{mg}-\mathrm{Kg}^{-1}$ and highest concentration of it was $5284 \mathrm{mg}^{-\mathrm{Kg}^{-1}}$ in blended hematite quartz (BHQ) soil sample. However, the concentrations of trace metals in the water samples were still within the permissible limits according to the drinking water quality standards of World Health Organization (WHO). To the date, extensive mining activities have not made any significant contribution to the heavy metal content of the studied water samples. The present study envisages on quantitative determination and impact of heavy metals in the surface water and soil samples due to mining.
\end{abstract}

Keywords: mining, heavy metals, water pollution, soil contamination, iron pollution, human health effect

\section{Introduction}

In mining operations, huge bulldozers and excavators are used to extract the metals and minerals from the soil. The major operation includes drilling and blasting, over burden dumping, mineral beneficiation, mine water pumping, contaminated waste water discharge and mineral transportation. Drilling and blasting operation contributes to explosive fumes while diesel equipments, generators and vehicular movement 
leads to increase in $\mathrm{NO}_{\mathrm{x}}$, hydrocarbons, carbon monoxide $(\mathrm{CO})$ and the level of lead in the atmosphere (Pereira et al.2008, Ratha et al. 1995, Rodrigueza et al.2009, Satapathy et al. 2009). The construction and mining in the proposed site drastically affects the environment. An environment degradation increases with the phase advancement in the mining (Satapathy et al. 2009). The processing of the minerals involves use of harmful chemicals which leads to the generation of toxic waste which affect the environmental attributes (Rodrigueza et al.2009, Satapathy et al. 2009, Zhang et al. 2010). The quality of environmental parameters like air, water, soil and noise gets deteriorated due to mining activity and requires continuous monitoring. Washing of equipments in the workshop, leakage of oil and grease in the working area and leachate from the dump site increases the possibility of water pollution. The runoff water from the mines contaminates the surface water resources during rainy seasons and is one of the reasons for pollution of water (Ratha et al., 1995, Huang et al. 2010, Liao et al. 2008). The activity of mining causes changes in the hydrological and hydro-geological characteristics of the surrounding area. Mining activity also causes changes in the erosion characteristics of the soil as well as flora and fauna pattern of the area (Iram S. et al, 2009, Zhang et al. 2010) Heavy metals represent a group of elements that occurs in natural environmental system in low concentration; however when they occur in sufficient quantities becomes toxic to humans (Rajappa et al., 2010, Huang; 2003). The major factors that affect the air quality of the mining area are drilling, blasting, crushing of iron ore and transportation of the minerals. Mining and metal processing activities led to distribution of metals in the surface environment. Iron ore mines acts as an important source of major metals; mainly Fe and Mn, and also contributes for trace metals into the environment (Ratha et al., Yellishettya et al. 2008, Xu et al. 2006). Various studies have confirmed the environmental 
contamination by trace metals in the iron quadrangle (Pereira et al. 2008, Olatunji 2009, Yellishettya et al. 2008).

This study aimed to identify the effect of iron ore mining and processing on quality of surface water through quantitative determination of trace metals. Study area is located at iron ore mines Rawghat, in the state of Chhattisgarh, India (Fig. 1).

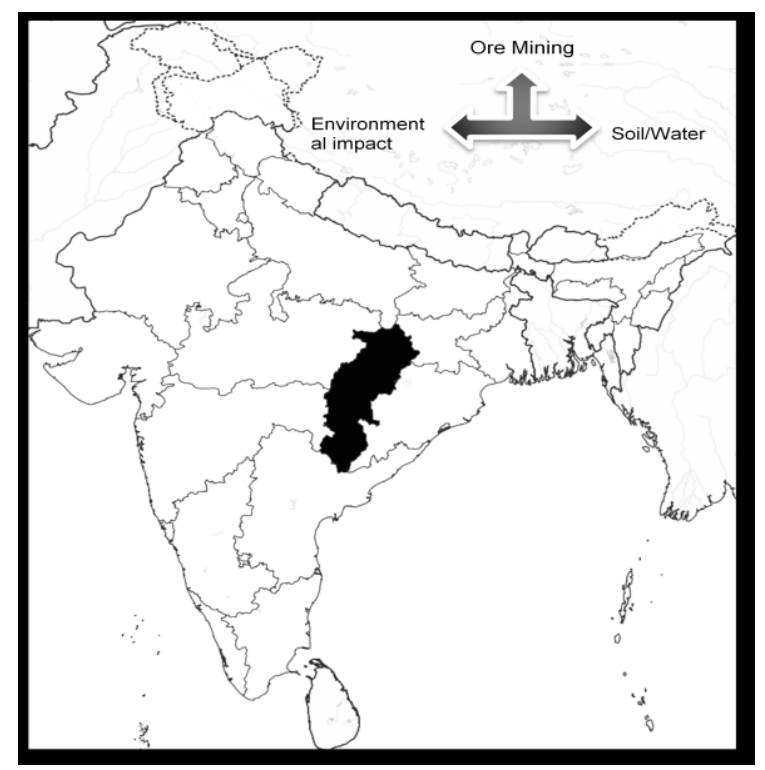

Fig. 1 Map of ore mines located in the state of

Chhattisgarh, India

In the present study, soil samples were collected from various mines sites (located at 20.580N 81.08E, at an average elevation of $409 \mathrm{~m}$ ) and from the surrounding villages. Water samples were collected from natural water bodies and hand pumps. These samples were quantitatively analyzed for the trace metals. The objective of the study was to investigate the metal pollution in the soil and in nearby water resources due to mining activity and to correlate it with water potability and possible effects on human health of the same.

\section{Materials and methods}

The study area includes various water resources in the town nearby the iron ore mines. To study the water quality of the water resources and soil contamination by trace metals, samples were collected 
in two different lots in the month of July. In first lot, three different soil samples and four different water samples had been collected. In the second lot, water samples from three different water bodies and five hand pumps along with eight soil samples from the different villages in the vicinity of mines had been collected. The concentration of heavy metals $\mathrm{Cd}, \mathrm{Cr}, \mathrm{Cu}, \mathrm{Co}, \mathrm{Fe}, \mathrm{Mn}, \mathrm{Ni}, \mathrm{Pb}$ and $\mathrm{Zn}$ were determined using inductively coupled plasma - atomic emission spectrometry (ICP-AES; model: GBC 904 AA, Australia). Determination of elemental carbon, nitrogen, hydrogen and sulphur was performed with CHNSO analyzer (model: Vario EL III, Elementar, Germany). The concentration of organic carbon and inorganic carbon content was also measured by microwave digested sediment samples with double distilled water and further analysis was done by total organic carbon (TOC) analyzer (Model: TOC Vcph, Shamidzu, Japan).

All the soil samples were sieved in a $2 \mathrm{~mm}$ stainless steel sieve to remove gravel particles and large detritus. Samples were oven dried at $60^{\circ} \mathrm{C}$ overnight to remove moisture until constant weight of the dried samples were obtained. Dried samples were then powdered in a mortar pestle to obtain fine powder. $1 \mathrm{~g}$ of each sample powder was digested in teflon vessel of microwave digestion system (Model: ETHOS 900) using 20 ml $\mathrm{HNO}_{3}$. Digested samples were filtered and made to known volume by deionised water. Analysis was carried out in triplicates to confirm the accuracy \& repeatability of the results.

\section{Result and Discussions}

In the present investigation, various soil and water samples nearby mining site were analyzed for trace metal content and the results so obtained depicts that all the trace metal except iron, zinc contents are well within the permissible range according to WHO standards (Guidelines for Drinking Water Quality, Fourth edition, World Health Organization, 2011). Three different soil samples were collected in the first lot from mine site viz. black soil, red soil and blended hematite 
quartz (BHQ) soil. Concentrations of metals detected in the samples were mostly in the normal range. Among the detected trace metals in all three studied soil samples, $\mathrm{Cd}$ was found only in black ore; $\mathrm{Ni}$ and $\mathrm{Zn}$ were found to be absent in black ore as well as in BHQ, whereas lead (Pb) was not detected in BHQ. Effect of iron ore mining activities can be seen through the concentration of iron which was substantially higher and was noted to be 218, 2568 and $5284 \mathrm{mg} / \mathrm{kg}$ in BHQ, red ore and black ore soil samples, respectively (Table 1 and Fig 2). $\mathrm{Zn}$ was the second most dominant metal in the tested samples and was found to be present only in the red ore soil sample (Fig. 2). From figure 2, it is also clear that the concentrations of $\mathrm{Cu}, \mathrm{Cd}$ and $\mathrm{Cr}$ were higher compared to the concentrations of these metals in BHQ soil. Results also shows that the concentrations obtained for $\mathrm{Mn}$ and $\mathrm{Ni}$ were higher in red ore soil when compared with other soil samples.

Table 1 Statistical Data on the Elemental Composition of the sediment samples collected from mines site $(\mathrm{mg} / \mathrm{kg})$.

\begin{tabular}{|c|c|c|c|c|c|c|c|c|}
\hline Samples & $\mathbf{C d}$ & $\mathbf{C r}$ & $\mathbf{C u}$ & $\mathbf{F e}$ & $\mathbf{M n}$ & $\mathbf{N i}$ & $\mathbf{P b}$ & $\mathbf{Z n}$ \\
\hline Black ore & $\begin{array}{c}0.32 \\
\pm 0.098\end{array}$ & $\begin{array}{c}6.14 \\
\pm 1.01\end{array}$ & $\begin{array}{c}10.08 \\
\pm 0.296\end{array}$ & $\begin{array}{c}5284 \\
\pm 884\end{array}$ & $\begin{array}{c}24.5 \\
\pm 2.29\end{array}$ & $\mathrm{ND}$ & $\begin{array}{c}1.24 \\
\pm 0.286\end{array}$ & $\mathrm{ND}$ \\
\hline Red ore & $\mathrm{ND}$ & $\begin{array}{c}2.6 \\
\pm 0.046\end{array}$ & $\begin{array}{c}8.44 \\
\pm 0.032\end{array}$ & $\begin{array}{c}2568 \\
\pm 18\end{array}$ & $\begin{array}{c}40.08 \\
\pm 1.76\end{array}$ & $\begin{array}{c}2.56 \\
\pm 0.018\end{array}$ & $\begin{array}{c}1.24 \\
\pm 0.064\end{array}$ & $\begin{array}{c}56.16 \\
\pm 0.066\end{array}$ \\
\hline BHQ & ND & $\begin{array}{c}0.36 \\
\pm 0.004\end{array}$ & $\begin{array}{c}0.5 \\
\pm 0.004\end{array}$ & $\begin{array}{c}218 \\
\pm 4.36\end{array}$ & $\begin{array}{c}0.96 \pm \\
0.03\end{array}$ & ND & ND & ND \\
\hline
\end{tabular}

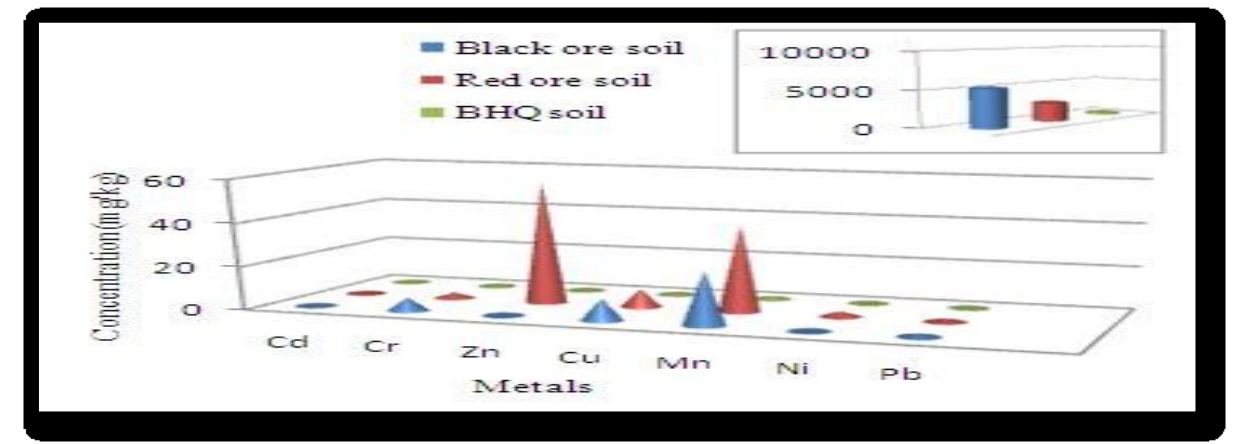

Fig. 2 Elemental composition of the sediment samples collected from mines site. Inset graph represents the composition of Iron in the sediment samples collected from mines site 
The samples collected from various water reservoirs used for drinking and agricultural purpose in the region were also analyzed to study the distribution of heavy metals due to mining activities. Only $\mathrm{Cu}, \mathrm{Fe}$, and Mn were found to be present in the runoff water sample and sample from Lohara Lake (Table 2 and Fig. 3), whereas other major trace metals were below the detectable limit. Percent $(\%)$ carbon $(\mathrm{C})$, nitrogen $(\mathrm{N})$, sulphur $(\mathrm{S})$ and hydrogen $(\mathrm{H})$ concentrations were also determined for all the soil and water samples (table 3). Organic carbon measured for water samples was found to be in the range of 20.5-123.5ppm.

Table 2 Statistical Data on the Elemental Composition of the samples collected from various water reservoirs $(\mathrm{mg} / \mathrm{L})$.

\begin{tabular}{|l|l|l|l|l|l|l|l|l|}
\hline Samples & $\mathbf{C d}$ & $\mathbf{C r}$ & $\mathbf{C u}$ & $\mathbf{F e}$ & $\mathbf{M n}$ & $\mathbf{N i}$ & $\mathbf{P b}$ & $\mathbf{Z n}$ \\
\hline Shivnath river & ND & ND & ND & ND & ND & ND & ND & ND \\
\hline $\begin{array}{l}\text { Runoff water at } \\
\text { mines }\end{array}$ & ND & ND & $\begin{array}{l}0.002 \\
\pm \\
0.0001\end{array}$ & $\begin{array}{l}0.336 \\
\pm \\
0.0125\end{array}$ & $\begin{array}{l}0.013 \\
\pm \\
0.0005\end{array}$ & ND & ND & ND \\
\hline Jawartala lake & ND & ND & ND & ND & ND & ND & ND & ND \\
\hline Lohara lake & ND & ND & $\begin{array}{l}0.005 \\
\pm \\
0.0001\end{array}$ & $\begin{array}{l}0.208 \\
\pm \\
0.0029\end{array}$ & $\begin{array}{l}0.013 \\
\pm \\
0.0002\end{array}$ & ND & ND & ND \\
\hline
\end{tabular}

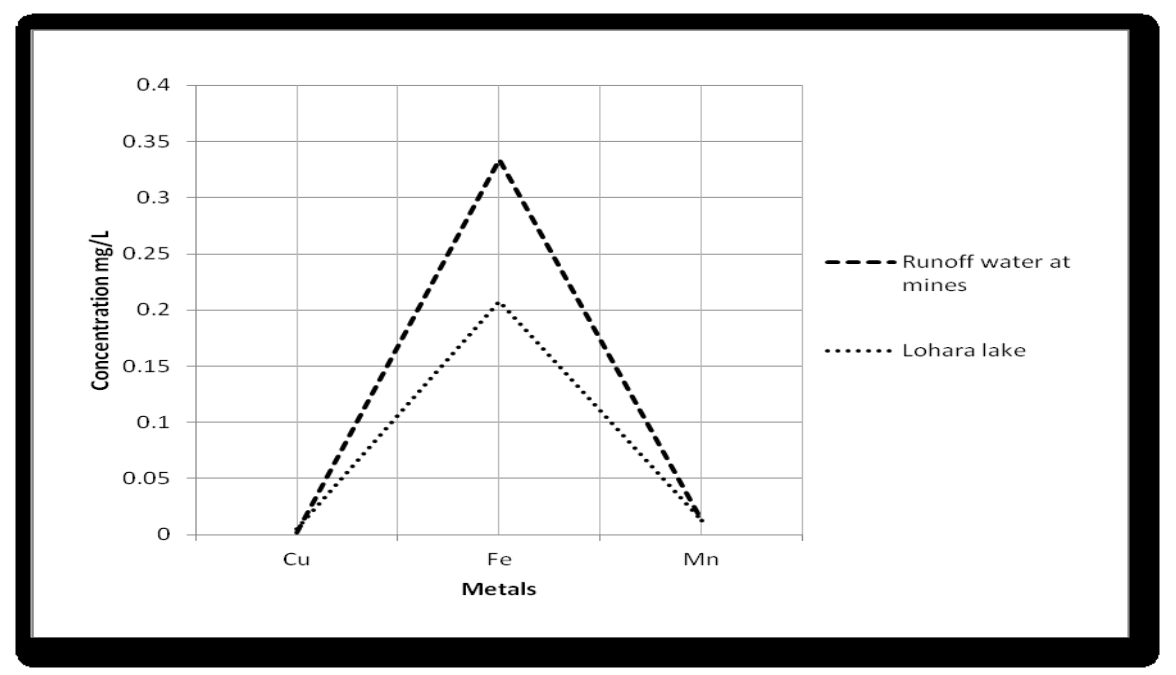

Fig. 3 Heavy metal composition in the water sample collected from different water reservoirs 
Table 3. Percentage elemental carbon, nitrogen, hydrogen and sulphur found in various samples

\begin{tabular}{|l|l|l|l|l|l|}
\hline Samples & \%N & \%C & \%S & \%H & C/N Ratio \\
\hline Black soil & 0.022 & 0.077 & 0.170 & 0.426 & 12.10 \\
\hline Red soil & 0.742 & 3.419 & 0.942 & 0.241 & 27.90 \\
\hline BHQ soil & 0.013 & 0.034 & 0.179 & 0.256 & 40.51 \\
\hline Shivnath river & 0.043 & 0.022 & 0.023 & 22.15 & 0.527 \\
\hline $\begin{array}{l}\text { Runoff water at } \\
\text { mines }\end{array}$ & 0.063 & 0.026 & 0.215 & 21.65 & 0.436 \\
\hline Jawartala lake & 0.034 & 0.022 & 0.055 & 23.26 & 0.667 \\
\hline Lohara lake & 0.034 & 0.031 & 0.056 & 25.85 & 0.973 \\
\hline
\end{tabular}

The next lot of surface and ground water samples, which were collected from 3 surface water bodies and from 7 different hand pumps, (distance and sampling locations of these from study area are listed in table 4) had also been investigated for heavy metal content.

Table 4 Water sampling locations in the study area

\begin{tabular}{|l|l|l|l|l|}
\hline \multicolumn{5}{|l|}{ Surface water } \\
\hline 1 & Dam & Boridih Dam & North North East & $5 \mathrm{~km}$ \\
\hline 2 & Dam & Jharam Dam & East South East & $7 \mathrm{~km}$ \\
\hline 3 & Dam & Tandula Tank & North East & $12.5 \mathrm{~km}$ \\
\hline \multicolumn{5}{|l|}{} \\
\hline 1 & Hround water & South West & $7.8 \mathrm{~km}$ \\
\hline 2 & Hand pump & Barsatola & East North East & $4.8 \mathrm{~km}$ \\
\hline 3 & Hand pump & Fugundak & East & $8 \mathrm{~km}$ \\
\hline 4 & Hand pump & Mucher & West North West & $5.3 \mathrm{~km}$ \\
\hline 5 & Hand pump & Bharitola & North & $5.3 \mathrm{~km}$ \\
\hline
\end{tabular}

Concentration of all the heavy metal tested for the water samples collected from these surface water bodies and groundwater samples falls well within the permissible limits of water quality standards, except $\mathrm{Cd}$ and $\mathrm{Pb}$ being marginally higher in surface water and iron exceeding the limits in ground water samples (Table 5). 
Table 5 Heavy metals concentration in water samples (mg/L)

\begin{tabular}{|c|c|c|c|c|c|c|c|c|c|c|}
\hline \multicolumn{2}{|c|}{ Dam } & $\mathrm{Ni}$ & $\mathrm{Cd}$ & $\mathrm{Cr}$ & $\mathrm{Cu}$ & $\mathrm{Pb}$ & $\mathrm{Fe}$ & Mn & $\mathrm{Zn}$ & Co \\
\hline 1 & $\begin{array}{l}\text { Boridih } \\
\text { Dam }\end{array}$ & ND & $\begin{array}{l}0.037 \\
\pm 0.004\end{array}$ & $\begin{array}{l}0.017 \\
\pm 0.002\end{array}$ & ND & ND & $\begin{array}{l}0.083 \\
\pm 0.004\end{array}$ & $\begin{array}{l}0.019 \\
\pm 0.001\end{array}$ & ND & $\begin{array}{l}0.008 \\
\pm 0.001\end{array}$ \\
\hline 2 & $\begin{array}{l}\text { Jharam } \\
\text { Dam }\end{array}$ & $\begin{array}{l}0.025 \\
\pm 0.003\end{array}$ & $\begin{array}{l}0.068 \\
\pm 0.003\end{array}$ & $\begin{array}{l}0.029 \\
\pm .002\end{array}$ & $\begin{array}{l}0.003 \\
\pm 0.001\end{array}$ & $\begin{array}{l}0.070 \\
\pm 0.003\end{array}$ & $\begin{array}{l}0.436 \\
\pm 0.07\end{array}$ & $\begin{array}{l}0.012 \\
\pm 0.001\end{array}$ & $\begin{array}{l}1.894 \\
\pm 0.05\end{array}$ & $\begin{array}{l}0.012 \\
\pm 0.002\end{array}$ \\
\hline 3 & $\begin{array}{l}\text { Tandula } \\
\text { tank }\end{array}$ & $\begin{array}{l}0.024 \\
\pm 0.002\end{array}$ & $\begin{array}{l}0.013 \\
\pm 0.006\end{array}$ & ND & ND & $\begin{array}{l}0.077 \\
\pm 0.002\end{array}$ & $\begin{array}{l}0.0651 \\
\pm 0.002\end{array}$ & $\begin{array}{l}0.023 \\
\pm 0.003\end{array}$ & $\begin{array}{l}0.013 \\
\pm 0.03\end{array}$ & $\begin{array}{l}0.010 \\
\pm 0.001\end{array}$ \\
\hline \multicolumn{11}{|c|}{ Ground water } \\
\hline 1 & Nalkasa & $\begin{array}{l}0.033 \\
\pm 0.003\end{array}$ & $\begin{array}{l}0.046 \\
\pm 0.002\end{array}$ & $\begin{array}{l}0.016 \\
\pm 0.003\end{array}$ & $\begin{array}{l}0.012 \\
\pm 0.001\end{array}$ & $\begin{array}{l}0.149 \\
\pm 0.1\end{array}$ & $\begin{array}{l}1.974 \\
\pm 0.1\end{array}$ & $0.0821 \pm 0.02$ & $\begin{array}{l}1.798 \\
\pm 0.15\end{array}$ & $\begin{array}{l}0.024 \\
\pm 0.002\end{array}$ \\
\hline 2 & Barsatola & $\begin{array}{l}0.019 \\
\pm 0.11\end{array}$ & $\begin{array}{l}0.068 \\
\pm 0.002\end{array}$ & $\begin{array}{l}0.025 \\
\pm 0.005\end{array}$ & ND & $\begin{array}{l}0.055 \\
\pm 0.001\end{array}$ & $\begin{array}{l}0.244 \\
\pm 0.12\end{array}$ & $\begin{array}{l}0.076 \\
\pm 0.001\end{array}$ & $\begin{array}{l}0.119 \\
\pm 0.12\end{array}$ & $\begin{array}{l}0.012 \\
\pm 0.002\end{array}$ \\
\hline 3 & Fugundak & $\begin{array}{l}0.020 \\
\pm 0.001\end{array}$ & $\begin{array}{l}0.062 \\
\pm 0.002\end{array}$ & $\begin{array}{l}0.016 \\
\pm 0.003\end{array}$ & ND & $\begin{array}{l}0.093 \\
\pm 0.07\end{array}$ & $\begin{array}{l}0.834 \\
\pm 0.1\end{array}$ & $\begin{array}{l}0.036 \\
\pm 0.001\end{array}$ & $\begin{array}{l}0.107 \\
\pm 0.05\end{array}$ & $\begin{array}{l}0.003 \\
\pm 0.001\end{array}$ \\
\hline 4 & Mucher & $\begin{array}{l}0.026 \\
\pm 0.001\end{array}$ & $\begin{array}{l}0.063 \\
\pm 0.003\end{array}$ & $\begin{array}{l}0.025 \\
\pm 0.002\end{array}$ & ND & $\begin{array}{l}0.070 \\
\pm 0.001\end{array}$ & $\begin{array}{l}0.097 \\
\pm 0.003\end{array}$ & ND & $\begin{array}{l}1.158 \\
\pm 0.18\end{array}$ & $\begin{array}{l}0.003 \\
\pm 0.001\end{array}$ \\
\hline 5 & Bharitola & $\begin{array}{l}0.025 \\
\pm 0.002\end{array}$ & $\begin{array}{l}0.067 \\
\pm 0.007\end{array}$ & $\begin{array}{l}0.034 \\
\pm 0.004\end{array}$ & ND & $\begin{array}{l}0.068 \\
\pm 0.002\end{array}$ & $\begin{array}{l}0.844 \\
\pm 0.02\end{array}$ & $\begin{array}{l}0.085 \\
\pm 0.001\end{array}$ & $\begin{array}{l}0.065 \\
\pm 0.001\end{array}$ & $\begin{array}{l}0.015 \\
\pm 0.001\end{array}$ \\
\hline
\end{tabular}

However, the soil sample collected from 8 different locations (from some of which, water samples have also been collected) found to be highly polluted with iron which was being detected in the range of $2092-3106$ mg-kg-1 of soil. Samples from Bharitola and Mucher have been found to contain lead in the concentration of 14.8 and $6.2 \mathrm{mg} / \mathrm{kg}$ of soil. Highest concentration of $\mathrm{Cd}$ was found in the soil of Nalkasa and Bharitola, respectively $(2.8 \mathrm{mg} / \mathrm{kg})$, whereas highest concentration of $\mathrm{Cr}$ was detected in the Fugundak's sample. Mucher's soil sample was found to contain the $\mathrm{Co}$ and $\mathrm{Cu}$ in higher range with concentration of 6.73 and $37.8 \mathrm{mg} / \mathrm{kg}$. $94.2 \mathrm{mg} \mathrm{Kg}^{-1}$ was the highest concentration of Mn which was found in the sample collected from Barsatola. Table 6 can be referred for detail comprehensive account of the concentration ranges of different soil sample. 
Table 6 . Heavy metals concentration in soil samples $(\mathrm{mg} / \mathrm{Kg})$

\begin{tabular}{|l|l|l|l|l|l|l|l|l|l|l|}
\hline \multicolumn{2}{|l|}{ Water bodies } & $\mathrm{Cd}$ & $\mathrm{Cr}$ & $\mathrm{Co}$ & $\mathrm{Cu}$ & $\mathrm{Fe}$ & $\mathrm{Mn}$ & $\mathrm{Ni}$ & $\mathrm{Pb}$ & $\mathrm{Zn}$ \\
\hline 1 & Boridih & 2.1 & 86.7 & 3.37 & 35.3 & 3023.0 & 57.25 & 8.75 & $\mathrm{ND}$ & 66.8 \\
& & \pm 0.2 & \pm 1.50 & \pm 0.33 & \pm 2.35 & \pm 155.8 & \pm 2.53 & \pm 0.38 & & \pm 2.10 \\
\hline 2 & Bharitola & 2.8 & 53.0 & 3.48 & 11.3 & 3106.0 & 15.39 & 26.24 & 14.8 & 132.2 \\
& & \pm 0.25 & \pm 1.04 & \pm 0.25 & \pm 0.75 & \pm 97.01 & \pm 1.02 & \pm 1.12 & \pm 1.32 & \pm 4.04 \\
\hline 3 & Mucher & 2.5 & 82.7 & 6.73 & 37.8 & 3056.0 & 88.91 & 27.13 & 6.2 & 70.7 \\
& & \pm 0.25 & \pm 0.68 & \pm 0.42 & \pm 1.50 & \pm 41.25 & \pm 2.06 & \pm 0.93 & \pm 0.08 & \pm 2.50 \\
\hline 4 & Barsatola & 2.0 & 78.5 & 4.65 & 26.3 & 3049.0 & 94.2 & 9.22 & $\mathrm{ND}$ & 99.2 \\
& & \pm 0.31 & \pm 3.01 & \pm 0.15 & \pm 1.25 & \pm 105.0 & \pm 4.00 & \pm 0.73 & & \pm 3.52 \\
\hline 5 & Dondi & 2.5 & 48.2 & 2.53 & 17.1 & 2885.0 & 43.9 & 6.55 & $\mathrm{ND}$ & 48.9 \\
& & \pm 0.30 & \pm 1.44 & \pm 0.21 & \pm 0.95 & \pm 48.42 & \pm 1.25 & \pm 0.50 & & \pm 118 \\
\hline 6 & Nalkasa & 2.8 & 55.7 & 2.11 & 34.3 & 2843.0 & 29.76 & 5.48 & $\mathrm{ND}$ & 70.8 \\
& & \pm 0.15 & \pm 2.007 & \pm 0.15 & \pm 1.52 & \pm 35.00 & \pm 0.82 & \pm 0.51 & & \pm 1.50 \\
\hline 7 & Fugundak & 2.7 & 96.4 & 3.43 & 29.2 & 2092.0 & 63.25 & 8.35 & $\mathrm{ND}$ & 70.8 \\
& & \pm 0.21 & \pm 2.60 & \pm 0.18 & \pm 1.55 & \pm 62.45 & \pm 0.53 & \pm 0.34 & & \pm 2.1 \\
\hline 8 & Jharantola & 2.7 & 51.4 & 2.92 & 10.7 & 3080.0 & 42.40 & 19.32 & $\mathrm{ND}$ & 125.3 \\
& & \pm 0.10 & \pm 0.9 & \pm 0.18 & \pm 0.793 & \pm 129.0 & \pm 0.44 & \pm 0.51 & & \pm 1.8 \\
\hline
\end{tabular}

\section{Conclusion}

The iron ore mining and processing constitute potential source of trace metals and it may contributes to metal pollution in the nearby water resources (Pereira et al.2008, Satapathy et al. 2009). Obtained values for heavy metals in the eater resources are within the permissible limits of specified WHO drinking water quality standards. The values obtained for elemental and organic carbon are higher whereas heavy metal contents are also within the permissible limit, so it can be used for extensive agricultural purposes. Data obtained in the study showed that the mining activities have not affected the quality of water and soil, except that the concentration of iron in all the soil samples tested was significantly higher. Though the iron concentration is exceptionally high in the soil samples, it has not polluted the water reservoirs but in future to keep these water reservoirs risk free, monitoring and assessment is extremely recommended. Findings in the present study may be useful for evaluating heavy metals exposure in more integrated way and will be helpful for future monitoring of heavy metal levels in the water and sediment samples to assess the environmental impact of the studied mine. 


\section{Acknowledgement}

Authors are thankful to the Director,CSIR- National Environmental Engineering Research Institute(CSIR- NEERI,) Nagpur, India for providing the laboratory facilities.

\section{References:}

Guidelines for Drinking Water Quality, Fourth edition, World Health Organization, (2011).

Huang X. (2003). Iron overload and its association with cancer risk in humans: evidence for iron as a carcinogenic metal. Mutation Research/Fundamental and Molecular Mechanisms of Mutagenesis 5332, 153-171.

Huang, X. A., Sillanpaa, M., Gjessing, E.T., Peraniemi, S., and Vogt, R.D., (2010). Environmental impact of mining activities on the surface water quality in Tibet: Gyama valley. Science of the total environment 19, 4177-4184.

Iram S., Ahmad I., and Stuben D., et al. (2009). Analysis of mines and contaminated agricultural soil samples for fungal diversity and tolerance to heavy metals. Pakistan Journal of Botany., 41(2), 885895

Islam M.M., Halim M.A., Safiullah S., Waliul Hoque S.A.M., Saiful I. M., (2009). Heavy Metal (Pb, Cd, Zn, Cu, Cr, Fe and Mn) Content in Textile Sludge in Gazipur, Bangladesh. Research Journal of Environmental Sciences 3, 311-315.

Liao G.L., Liao D.X., and Li Q.M., (2008). Heavy metals contamination characteristics in soil of different mining activity zones. Transactions of Nonferrous Metals Society of China 18, 207-211

Olatunji K.J., (2009). Organic Matter and Nutrients Depletion in Soil of Itakpe Iron Ore Deposit Area of Kogi State, Nigeria. Research Journal of Applied Sciences 4, 17-19.

Pereira A. A., Hattum B. V., Brouwer A., Bodegom M.P., Rezende C.E., and Salmons W., (2008). Effect of iron-ore mining and processing 
on metal bioavailability in tropical coastal lagoon. Journal of Soils and Sediments 8, 239-252.

Rajappa B., Manjappa S., and Puttaiah E. T., (2010). Monitoring of heavy metal concentration in ground water of Hakinaka Taluk, India. Contemporary Engineering Services 3, 18 -190.

Ratha D.S., and Venkataraman G., (1995). Environmental impact of iron ore mines in Goa, India. International Journal of Environmental studies $47,43-53$.

Rodrígueza L., Ruizb E., Alonso-Azcáratec J., and Rincónb J., (2009). Heavy metal distribution and chemical speciation in tailings and soils around a $\mathrm{Pb}-\mathrm{Zn}$ mine in Spain. Journal of Environmental Management 90, 1106-1116.

Satapathy D. R., Salve P. R., Katpatal Y. B., (2009). Spatial distribution of metals in ground/surface waters in the Chandrapur district (Central India) and their plausible sources. Environmental Geology $56,1323-1352$.

Xu Z., Hwang J., Greenlund R., Huang X., Luo J., and Anschuetz S.,2006. Quantitative determination of metallic Iron content in steel making slag. Journal of mineral and material characterization \& Engineering 2, 65-70

Yellishettya M., Karpeb V., Reddyb E.H., Subhashb K.N.,and Ranjitha P.G., (2008). Reuse of iron ore mineral wastes in civil engineering constructions: A case study. Resources Conservation and Recycling $52,1283-1289$.

Zhang F.P., Li C.F., Tong L.G., Yue L.X., Li P., Ciren Y.J., and Cao C.G., (2010). Response of microbial characteristics to heavy metal pollution of mining soils in central Tibet, China. Applied Soil Ecology 45, 144-151 